\title{
Spatial and socio-economic transformation of transhumance in gerger district (Southeast Turkey)
}

Muzaffer BAKIRCI

\begin{abstract}
Turkey has gone into a rapid process of transformation especially starting with the 80s. Un on trolled migration from rural areas to urban areas since this date, not only led rural areas to be emptied to a great extent, but also caused emergence of various structural problems in urban areas.

One of the forms of living in Turkey that were affected the most by the change and transformation experienced in rural areas is transhumance. Seminomadic animal husbandry carried out in almost all regions of Turkey and the lifestyle related to this face radical changes.

The Gerger district, located in southeast Turkey, is one of the areas that experienced this process of change most noticeably. Transhumance, which has been carried out for centuries here continuously, faces significant spatial, economic and socio-cultural transformations.

In spatial transformation, regression of animal husbandry activities based on natural environment conditions and occasional emergence of agricultural production become prevalent, while significant differentiations take place in types of residences. Animal husbandry, which used to be a main economic activity in the past, disappeared in dramatic rates and is almost no longer an activity that brings income, which indicates economic transformation; again, loss of influence of a set of social rules that used to be followed precisely and disappearing of some traditions indicate sociocultural transformation.

Keywords-Turkey, Gerger District, Transhumance, Spatial, Socio-Economic, Transformation
\end{abstract}

\section{INTRODUCTION}

$\mathrm{T}$ ranshumance (yaylacilik in Turkish), which indicates a semi-nomadic lifestyle and rises out of traditional animal husbandry activities, constituted an important part of Turkey's rural life for a very long time not only with its economic

Received: 10-10-2017, Accepted: 12-12-2017; Published: 30-6-2018

Muzaffer BAKIRCI, Istanbul University

Email: mubak@istanbul.edu.tr dimensions, but also in terms of spatial and sociocultural aspects.

Several scientific studies have been conducted for years on transhumance activities carried out in almost all regions in Turkey. While initial studies were in the form of establishing a conceptual framework of this issue and presenting its general characteristics [1], more recent studies investigated plateaus (yaylas in Turkish) rather in terms of functional change, tourism aspects, improvement of this function and examination of problems caused by change [2].

While studies on transhumance activities cover almost all regions in Turkey [3], it is seen that the focus is rather on scientific studies regarding the plateaus in the Black Sea Region [4]. The genuine part of the subject of this study is that no study has been conducted about Gerger plateaus despite the abundance of research on transhumance.

The Gerger district is an area in which transhumance activities have taken place continuously since very early times, while the changing conditions lead transhumance to be set back with its classical rural activities.

The main purpose here is to present the historical development, structural characteristics, current transformations and outcomes of these transformations regarding transhumance activities in the Gerger district of the province of Adiyaman, and create perspectives towards the future of these areas, using field observations, interviews and official statistics as the main methods and tools.

\section{CHARACTERISTICS OF THE PHYSICAL GEOGRAPHY}

Meadows and pastures located in the Gerger district of the province of Adiyaman in southeast Turkey at the altitudes of $1700-1900 \mathrm{~m}$. present suitable conditions for animal husbandry. Based 
on this potential, this area has been used for animal husbandry since early ages by the villages located in lower hills of the mountainous area.

The study area consists of the Avacik and Kurdek Plateaus in the north of the Gerger district (Figure 1). While these plateau areas are connected to each other, they have very different qualities in terms of their topographical features. While the Avacik plateau has a rather flat appearance, slopes of the hills in the Kurdek plateau are higher (Figure 2).

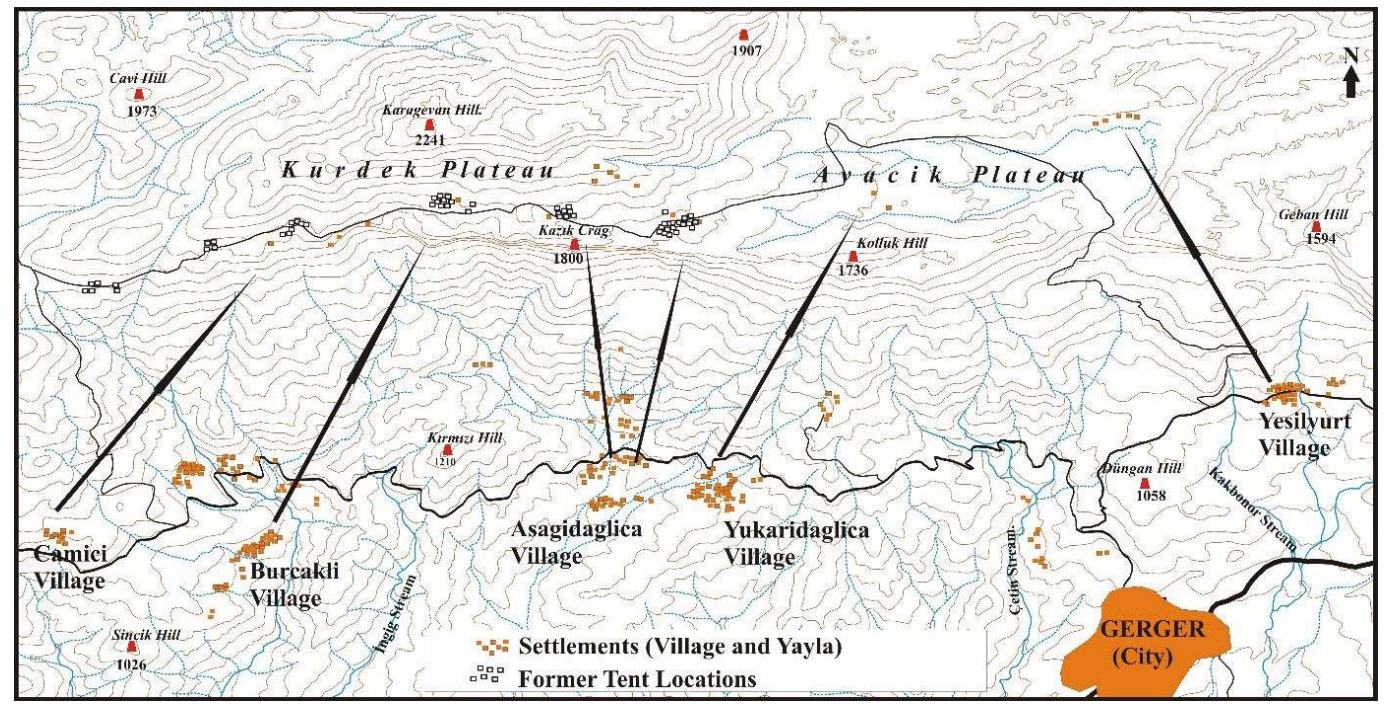

Figure 1. Topographical Appearance of the Plateau (Yayla in Turkish) Areas

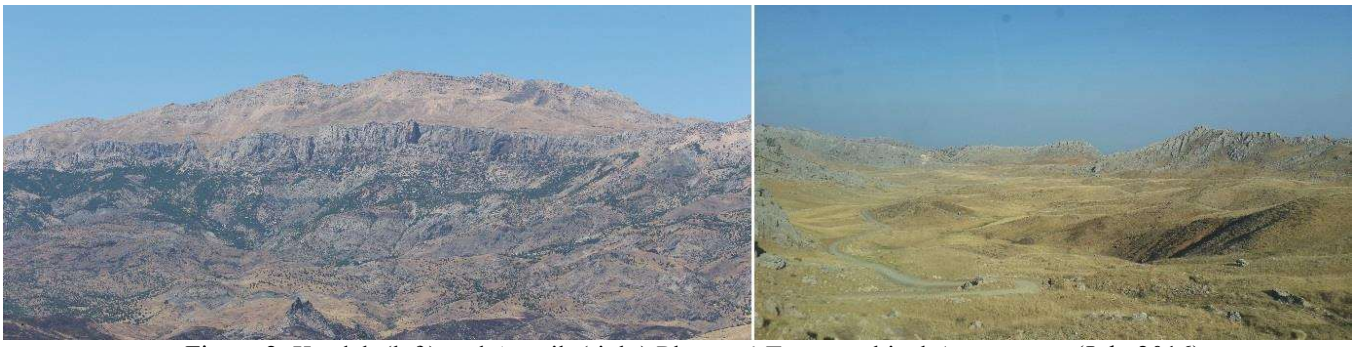

Figure 2. Kurdek (left) and Avacik (right) Plateaus' Topographical Appearance (July 2016)

\section{CHARACTERISTICS OF THE HUMAN GEOGRAPHY}

The transhumance activities in Gerger, whose history may be traced back 300 years [5], has continued without a break despite the events of terrorism effective in the Eastern and Southeastern Anatolia Regions of Turkey for more than 35 years.

Gerger plateau areas are utilized by villagers coming from different villages. In this framework, while the Avacik plateau is being used by the villagers of the Yesilyurt and Yukarıdaglica villages, the Kurdek plateau is being used by the villagers of the Asagidaglica, Burcakli and Camici villages (Figure 1).
While the Avacik plateau is about $5 \mathrm{~km}$ from the Yesilyurt village, its distance from the Gerger district center is about $8 \mathrm{~km}$. The Kurdek plateau is $13 \mathrm{~km}$ from the Gerger district center. Both plateau fields are visited in the middle of May (around 15 May), and the return takes place in the beginning of October (around 5-10 October) at the latest.

Considering the population characteristics of the transhumant villages in Gerger and their historical development, they are rather small-sized population villages (Table 1). The average size of the transhumant villages in 2015 was 230 . It is seen that the number of villages participating in transhumance activities had a general trend to rise till the year 1985, while this number experienced dramatic reductions after this time Figure 3. 
The total population of the 5 villages mentioned above was close to 1500 in 1955 , reached its maximum in 1990 (2636 people), and came down

to 1159 in 2015 . Thus, it decreased in 2015 by $22.6 \%$ based on the year 1955 and by $76.1 \%$ based on the year 1990 .

Table 1

Development of the Populations of the Villages Participating in Transhumance Activities in the Gerger District

\begin{tabular}{|c|c|c|c|c|c|c|c|c|c|c|c|c|}
\hline \multirow{2}{*}{ Villages } & \multicolumn{12}{|l|}{ Years } \\
\hline & 1955 & 1960 & 1965 & 1970 & 1975 & 1980 & 1985 & 1990 & 2000 & 2007 & 2010 & 2015 \\
\hline Asagidaglica & 386 & 450 & 459 & 359 & 591 & 659 & 663 & 588 & 403 & 336 & 312 & 250 \\
\hline Burcakli & 378 & 451 & 444 & 537 & 629 & 691 & 695 & 701 & 488 & 382 & 431 & 282 \\
\hline Camici & 392 & 385 & 445 & 536 & 634 & 599 & 533 & 488 & 303 & 257 & 268 & 167 \\
\hline Yesilyurt & 0 & 0 & 0 & 0 & 0 & 0 & 0 & 392 & 276 & 213 & 195 & 155 \\
\hline Yukaridaglica & 341 & 357 & 332 & 439 & 435 & 504 & 496 & 467 & 447 & 407 & 392 & 305 \\
\hline Villages Total & 1497 & 1643 & 1680 & 1871 & 2289 & 2453 & 2387 & 2636 & 1917 & 1595 & 1598 & 1159 \\
\hline District Total & 19749 & 22494 & 26723 & 29395 & 30820 & 30380 & 32618 & 32587 & 27208 & 25811 & 24622 & 19561 \\
\hline
\end{tabular}

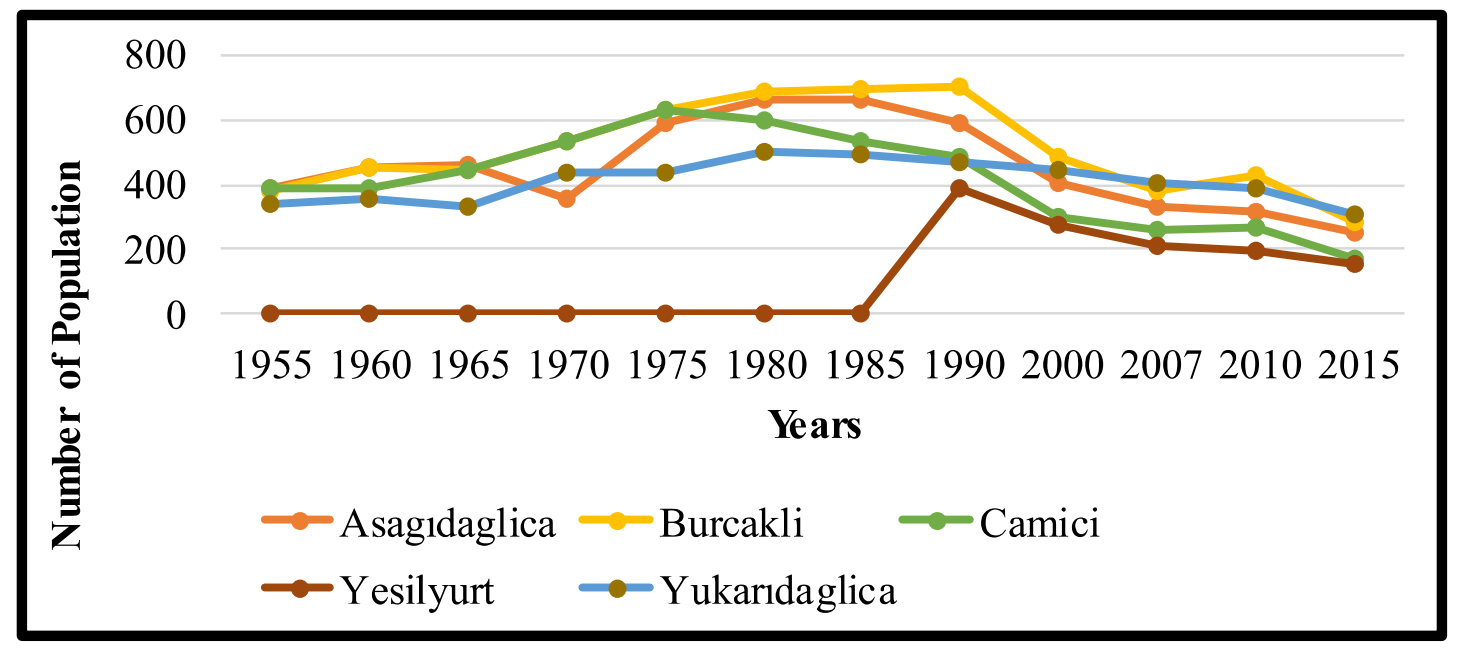

Figure 3. Development of the Populations of the Villages Participating in Transhumance Activities in the Gerger District

\section{SPATIAL AND SOCIO-ECONOMIC TRANSFORMATION IN THE GERGER PLATEAUS}

The economic transformation experienced in plateaus bring about differentiations in spatial usage. While this differentiation may be related to animal husbandry and plant-based production in plateau fields, forming new structures in the plateaus that are becoming subjects of tourism is another issue of concern. This situation leads to the emergence of new units that are not seen in traditional transhumance.

The activity of transhumance which has turned into a lifestyle over centuries harbors genuine behaviors, acts and symbols within itself. This rapid change in transhumance may result in flexibility or complete abandonment of rules that were previously applied very strictly.

\subsection{Change in Land Usage}


Spatial utilization that has been going on without much intervention in the Gerger plateaus has gone into a rapid process of change in the last 10-15 years. It is seen that these pastures that have been utilized in suitability of their natural qualities for a long time have gone into a partial change in time, and agricultural production emerged. Various fruit trees located around the lands organized by the people of the region with agricultural purposes present a new appearance (Figure 4).
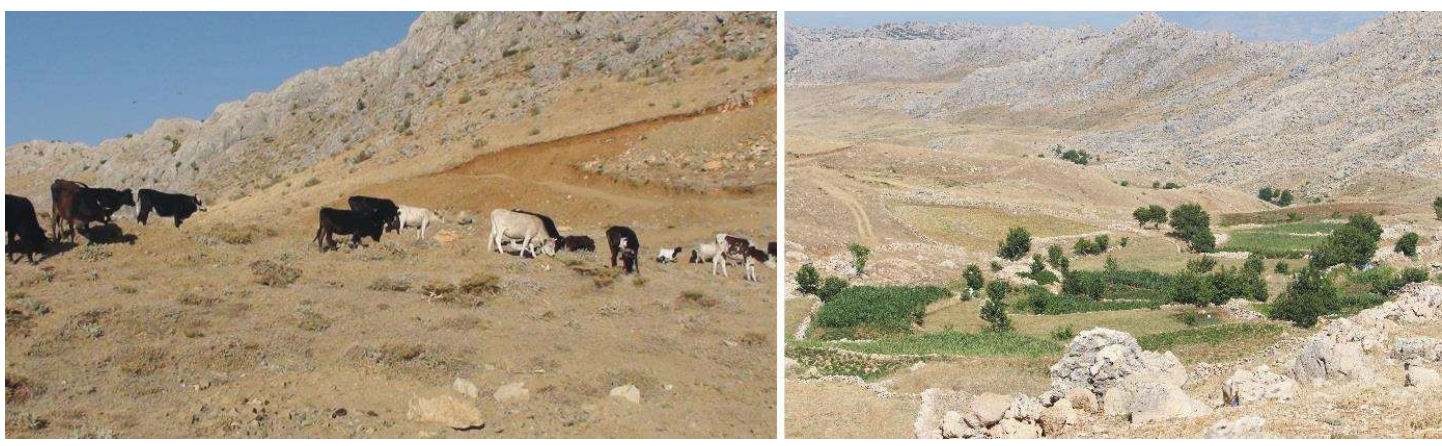

Figure 4. Change in Land Utilization in the Gerger Plateaus (July 2016).

\subsection{Change in Residence Characteristics}

While the plateaus are very close to each other, the plateau residence structure in the form of "tents" in the Kurdek plateau is matched by the traditional residences called "Hol" in the Avacik plateau. Transhumance, which had been realized by accommodation in the traditional residences mentioned about till 2000, went into a rapid process of change starting with the year 2001 .

While the tents set up in the Gerger Kurdek plateau in the past appeared like neighborhoods of tents (Map 4), very few tents are seen today and tents are being replaced by concrete houses (Figure 5).
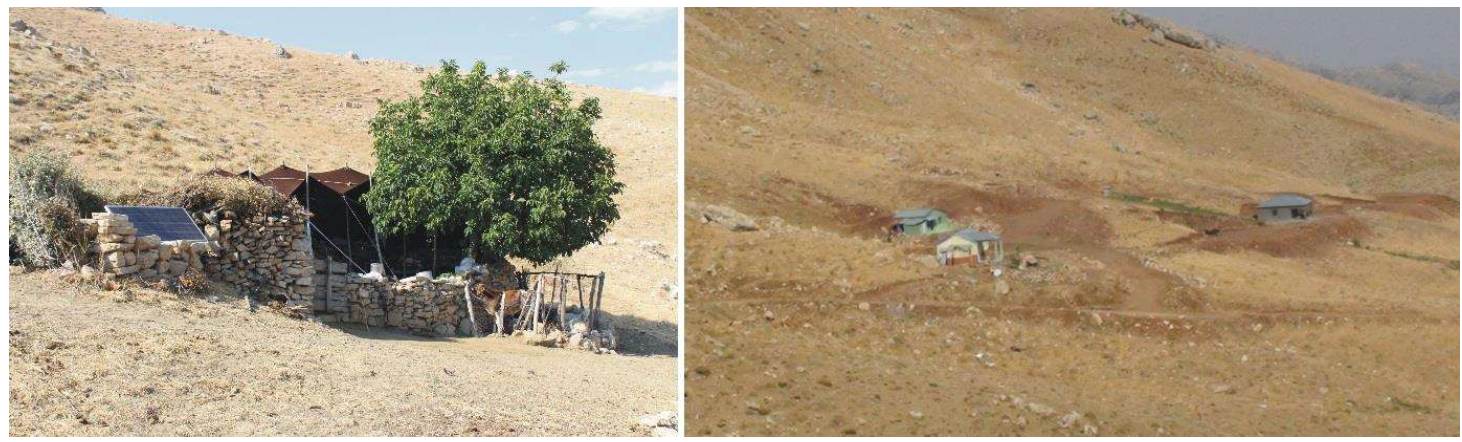

Figure 5. Tent Residences in the Kurdek Plateau are Rapidly Being Replaced by Concrete Houses (July 2016).

Utilizers of the Avacik plateau have taken accommodation in residences that are called "Hol" instead of tents, by using the means provided to them by the topography. The hills surrounding the plateau have provided the ideal conditions for accommodation by the transhumant residents. Hol residences were formed by reorganization of the crevices and small holes in the hills (Figure 6).

While over 40 Hols were seen in the Avacik plateau in the past, which indicates intensity of usage, it was seen that there was one Hol in usage in the plateau in July 2016 and these residences are being replaced by concrete houses as in the case of the Kurdek plateau (Figure 7).

Another issue to mention about the subject of new housing in the Kurdek plateau where a rapid process of settlement is takin place is that most of the residences being constructed here are not dedicated for transhumance activities, but they serve as second homes for people who previously took part in transhumance activities and are now living in metropolitan cities. 

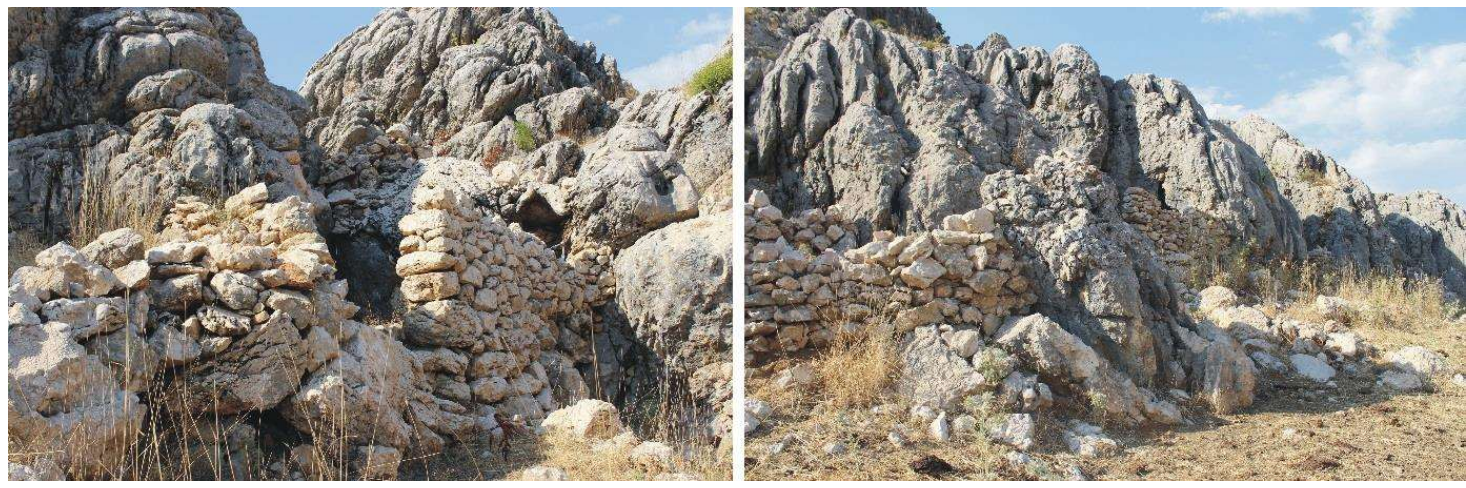

Figure 6. The Traditional Residences of the Avacik Plateau: Hols (July 2016)
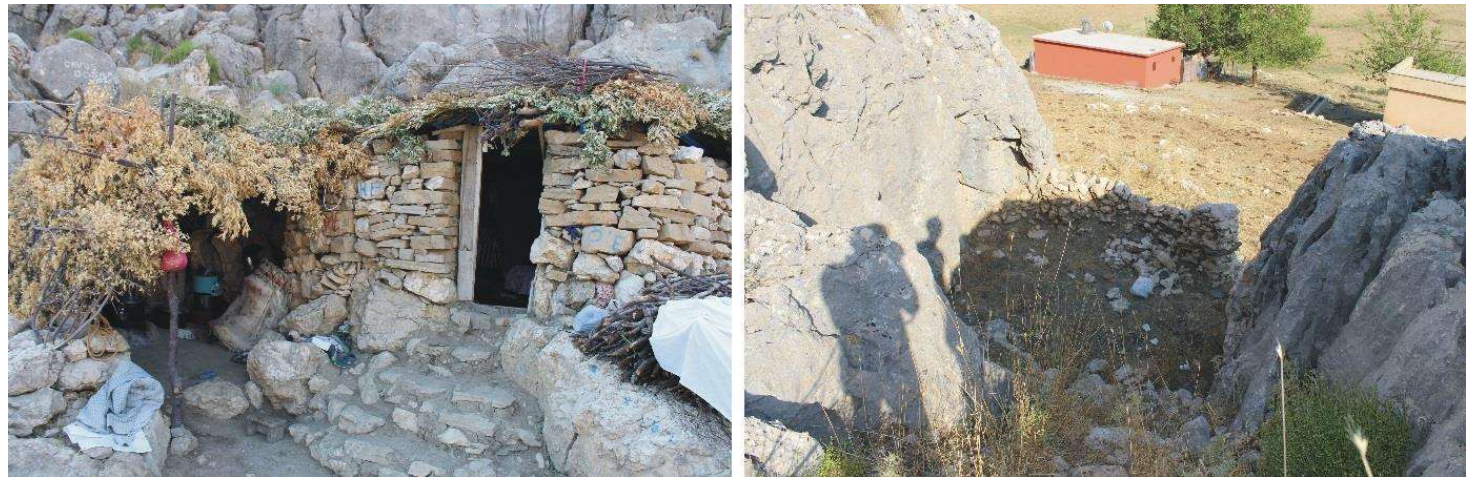

Figure 7. A Hol in Usage (left) and Concrete Houses (July 2016)

\subsection{Economic Change}

Especially the number of people who take part in animal husbandry activities in the Gerger plateaus has receded a lot in comparison to 20 years ago. Records of tent areas that harbored about 60 tents in 6 locations in 1990s in the Kurdek plateau on topography maps (Map 2), and similarly, the noticeable places for traditional plateau residences called $\mathrm{Hol}$ in the Avacik plateau, indicate that these two plateaus had high rates of utilization in the past.

The statements of the people of the area indicate that, in the past, the villages of Yesilyurt, Yukaridaglica, Asagidaglica, Camici and Burcakli participated in this activity with attendance of all villagers. In a field study in 2013, it was understood that 13 households arrived at the Avacik plateau. On the other hand, it was learned that 30 households took part in transhumance activities in the Kurdek plateau. It was seen that these numbers decreased even more in the observations made in 2016.

It may be seen that not only the number of households who visit the plateau, but accordingly, the number of animals kept also decreased dramatically. Examples of the size of change in the number of animals may include the fact that the number of animals known as thousands in 1990s decreased down to numbers such as 300 500 , and while each household had at least 30 goats and 5-6 cows in 1990s, now they have 5-10 goats and a few cows.

The economy of plateau areas which has taken place for long years in the form of pastoral farming, gained a new dimension by introduction of agricultural production. In agricultural production, which is increasingly becoming one of the main economic activities in these areas, the locals produce various fruits especially including walnuts and pomegranates, and various vegetables especially including corn, tomatoes, peppers and onions. It is projected that agriculture-based utilization of plateau areas will be even more prevalent in the future. One of the indicators supporting this idea is the existence of small agricultural areas that are newly formed. Agricultural production is not the only thing that is added onto animal husbandry as a traditional activity in the Gerger plateaus, but beekeeping has also started to appear more frequently (Figure 8). 

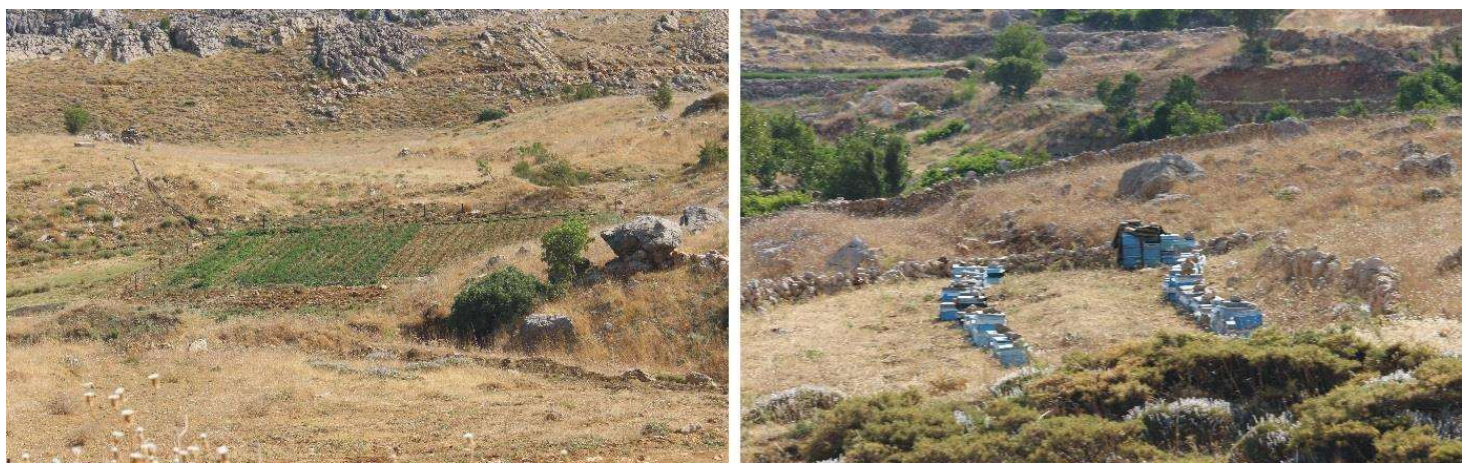

Figure 8. The New Agricultural Land Formed in the Avacik Plateau (left) and Beekeeping in the Kurdek Plateau (right).

\subsection{Social Change}

Transhumance as a lifestyle is one of the strong factors that shape the social structure. This strong aspect sets the ground for the development of genuine behaviors, rules and traditions of transhumance. In this sense, there are unwritten but strongly enforced rules in the operation of transhumance activities. At this stage, the most important priority is claiming and protecting the plateau area. This is so essential that usage or claiming of the area by dwellers of other villagers may lead to great conflicts.

According to the traditional rules of transhumance, it is essential that transhumant villages visit the same plateau every year, and even use the same tent or Hol location. Another issue we see in the tradition of transhumance is the necessity of acting together. This is based on the desire of achieving justice in terms of utilizing the plateau area that belongs to the village. For example, Yesilyurt villagers who use the Avacik plateau gather at the side of the plateau on a certain day and time, and start running from the side to the grazing area with the command to run. The main purpose of this is that the fastest running person gets the best and bushiest grazing area.

Not only in the beginning of the plateau season but also along the period the activity goes on, various events are organized and time is spent by playing games, particularly with participation of the men, young people and children of the plateau.

Today, the reduced number of households and therefore their animals visiting the plateau creates a potential for losing the old environment of competition in both providing fresh grass and obtaining grass for winter, and this situation results in the abandonment of applying a set of rules that were previously regulatory.
Besides this, there is a search for gaining new functions in plateaus. An example for this search is tourism activities. Adoption of tourism function by plateaus generally happens in two different forms. One of these is beginning to use these areas for recreation (second home) by constructing modern houses in plateau areas, and the other is the plateau festivals held in different times of the year.

While the Gerger plateaus are not very vibrant in terms of tourism movement, it is observed that the two types of change mentioned above have partially taken place. While the desire of the population that previously took part in transhumance activities but are now living in metropolitan cities to spend some part of the year here brings second homes into question, cultural transformation is indicated by the "Kurdek Plateau Festival" organized for the first time in 2013 in order to create awareness about the Gerger plateaus and take some tourism-oriented steps towards the future.

\section{PROBLEMS IN UTILIZATION OF THE GERGER PLATEAUS}

There are problems in utilizing the Gerger plateaus caused by the infrastructure, property and usage rights, social and economic conditions.

\subsection{Problems Related to Spatial Usage}

The primary issues regarding spatial usage in the Gerger plateaus are transportation conditions. While there are some developments in transportation activities that were previously achieved completely on animals' backs or on foot, these developments are not on a sufficient level. While it is possible to reach the plateau area with motorized vehicles today, poor quality of the 
roads poses as an obstruction against reaching these areas with any kind of motorized vehicle.

The indispensable necessity of the modern world, electricity, is another problem experienced in plateau sites. There are currently no transfer lines that will carry electricity, while there is no current tangible work put into it either.

Another problem experienced in plateau sites is about water needs. It is inevitable to experience problems with water needs even in spring months, particularly in years without sufficient snowfall.

\subsection{Administrative Problems}

The sites that have been used by certain villages for centuries and accepted as the common property of the village have occasionally led to conflicts among transhumant villagers, and this situation has limited peaceful utilization of plateau sites.

\subsection{Social Problems}

Migration, especially by the young population mostly due to economic reasons, brings traditional transhumance that is oriented around animal husbandry to a brink of disappearance. There is currently no planning about where this transformation will end up in the future.

Desires and efforts to achieve survival of plateau traditions on one hand, and the realities of life especially regarding economic conditions on the other hand, bring about a dilemma about the future of the Gerger plateaus.

\subsection{Economic Problems}

The difficulty of carrying out animal husbandry in traditional conditions is a restricting factor in continuation of this activity by the new generation. On the other hand, while animal husbandry brings a good income, it is more attractive for the young village population to live in the city.

The agricultural production carried out with the purpose of supporting the animal husbandry activities in the plateau sites is currently far from being on a scale that will revive the economy of the plateau.

While beekeeping has increasing importance, it is not an organized activity. Despite this issue, beekeeping has the quality of having the highest potential for development in the short-run among economic activities that may be carried out in these sites.

Finally, it does not seem possible in the shortrun to conduct activities towards tourism in the
Avacik and Kurdek plateaus of Gerger and create income from such activities.

\section{DISCUSSION AND CONCLUSION}

Undeniably, it is an area of social responsibility for both the public and the authorities to protect the traditions that are historical memories of countries and transfer them to new generations.

In the Gerger plateaus, it does not seem possible to completely preserve this lifestyle that has been shaped in the harsh conditions of the past and protected its form for a long time. With the difficulties of this lifestyle combined with the belief in the existence of better living conditions in cities, it is not possible to prevent rapid migration out of the area.

The issue that may be addressed first in terms of the economic dimension of the activity of transhumance, is that it promotes combined modern animal husbandry in integration with the village sites. Not only improving animal husbandry activities but also processing the animal products created and transporting these to consumption sites by packing, will create a significant income and area of living.

Another issue to be emphasized in terms of transhumance is the agricultural production that is being carried out to a limited extent. This production has a potential to turn into an important item of income in the case that it is conducted in a more planned and goal-oriented fashion.

Local goods that are especially sought after in urban areas and attract higher prices, and goods that are produced in natural conditions, have a potential to make a significant contribution to the local economy. In this context, it is crucial that good agriculture and organic agriculture practices are employed in plateau sites and villages that are close to these sites.

One of the most negative aspects in the spatial reorganization of the transhumance sites is the concrete buildings that are rapidly replacing Tents and Hols, which are the traditional residences in the Gerger plateaus. Understandably, it would not be rational to suggest that the locals should continue living in Tents and Hol residences, which are very primitive shelters. However, the new structures should be expected to represent a local meaning and culture.

When one thinks about tableland tourism in the region, while it is not expected to reach a very 
advanced level currently and in the near future, it is clear that the residences built in our time will not contribute to improvement. Indeed, it is seen that these are even far from filling the place of the traditional tents and Hols.

Accordingly, the following may be recommended;

1 Some sites in the plateaus should be designated as residence areas, and only these sites should be allowed for building residences.

2 Residences built using the stone material that can be easily found in the region will result in an aesthetical appearance.

3 Multi-story (3 or more floors) building should not be allowed in plateau residences.

4 An architectural character should be established in the plateau residences to be built, and it should be aimed to reflect the customs and traditions of local residences while doing this.

While the Gerger plateaus have a significant potential in terms of elements of natural tourism, it is hard to say that social conditions are able to accompany this potential sufficiently. While there are currently no activities that will stimulate tourism in the study area, it is seen that there is no planning towards this purpose either. Absence of facilities towards satisfying transportation, marketing and basic needs shows that it will not be possible for tourism to develop in the region with the natural flow of events.

Consequently; as the region does not generally provide satisfying economic conditions, it continues to trigger emigration from the district. On the other hand, despite all the negativities, the Gerger region in general and the plateau sites in it in particular, have significant potentials. The site is waiting for capable hand that will revive the potentials it has in modern animal husbandry, organic agriculture and rural tourism.

\section{ACKNOWLEDGEMENT}

This work was supported by Research Fund of Istanbul University, Project Number: BEK-201724193.

\section{REFERENCES}

[1]. Alagöz C. A., Anadolu'da Yaylactlk. CHP Konferansları Serisi No: 1. Ankara. 1938.
(Transhumance in Anatolia. CHP Conferences Series No: 1,1938. Ankara)

[2]. Leidenfrost K., Pasher, O., Yaylacllk. Ormancilık Araştırmaları Enstitüsü Yayını. Ankara. 1969. (Transhumance. Institute of Forestry Research Publications. Ankara. 1969)

[3]. Tunçdilek N., Türkiye'de Yaylalar ve Yaylacılık. İstanbul Üniversitesi, Coğrafya Enstitüsü Dergisi. Sayı 14. İstanbul.1964.15-28. (Yayla Settlements and Transhumance in Turkey. Istanbul University, Journal of Geography Institute. Issue 14 Istanbul. 1964. 15-28)

[4]. Emiroğlu M., Bolu'da Yaylalar ve Yaylacılı. Ankara Üniversitesi Dil ve Tarih Coğrafya Fakültesi Yayınları. No: 272. Ankara. 1977. (Yayla Settlements and Transhumans in Bolu. University of Ankara Faculty of Language and History-Geography Publications. No: 272. Ankara. 1977)

[5]. Bekdemir Ü., Özdemir Ü., Doğu Karadeniz Bölümünde Gelişmekte Olan Yayla Turizm Merkezlerine Bir Örnek: Bektaș Yaylası. Doğu Coğrafya Dergisi. Cilt 7. Sayı: 7. Erzurum. 2002. 9-35. (An Example of Developing Yayla Tourism Centers in the Eastern Blacksea Region: Bektaş Yaylasi. Journal of Eastern Geography. Volume 7, Number 7: Erzurum. 2002. 9-35)

[6]. ITO, Karadeniz Bölgesinde Yayla Turizminin Geliştirilmesi, Bölgesel Gelişme ve Çevreyle Uyumlu Yapılaşma. İstanbul Ticaret Odası Yayını. İstanbul. 1997. (Development of Yayla Tourism in the Black Sea Region, Regional Development and Reconciliation with Environment. Istanbul Chamber of Commerce Publication. Istanbul. 1997)

[7]. Zaman M., Geleneksel Yayla Şenliklerinin Doğu Karadeniz Yayla Turizminin Geliştirilmesindeki Rolü. Doğu Coğrafya Dergisi, Cilt 7 Sayı: 6. Erzurum. 2001. 188-214 (The Role of Traditional Yayla Festivals in Development of the Eastern Blacksea Yayla Tourism. Journal of Eastern Geography, Volume 7: 6. Erzurum. 2001. 188-214)

[8]. Doğanay H., Coşkun O., Türkiye Yaylacıllğındaki Değişme Eğilimleri ve Başlıca Sonuçlart. Doğu Coğrafya Dergisi., Cilt 18. Sayı 30. Erzurum. 2013. 1-30 (Changing Trends and Main Results on Transhumans in Turkey. Journal of Eastern Geography, Vol. 18. Issue 30. Erzurum. 2013. 1-30)

[9]. Güner İ., Ertürk M., Fethiye'de Yaylalar ve Yaylacılı. Doğu Coğrafya Dergisi, Cilt 10. Say1: 14. Erzurum. 2005. 141-178 (Yayla Settlements and Transhumance in Fethiye. Journal of Eastern Geography, Volume 10: 14. Erzurum. 2005. 141-178)

[10]. Gürbüz M., Dibek Dağları'nda (Göksun) Kar Suyuna Bağll Olarak Yapılan Yaylactlı. Türk Coğrafya Dergisi. Say1 34. İstanbul. 1999. 661-677 (Yaylacilik in Dibek Mountains (Göksun) Due to Snow Flood. Turkish Geographical Review. Number 34. Istanbul. 1999. 661677)

[11]. Sözer A. N., Kuzeydoğu Anadolu'da Yaylacllk. Turhan Kitabevi. Ankara. 1972. (Yaylacilik in Northeast Anatolia. Turhan Publishing. Ankara. 1972)

[12]. Aydınözü D., Solmaz F., 2003, Doğu Karadeniz Bölümü Yaylacıllk Faaliyetlerine Bir Örnek: Giresun Kümbet Yaylası. Gazi Üniversitesi. Gazi Eğitim Fakültesi Dergisi. Cilt 23. Say1 3. Ankara. 2003. 55-69 (An Example of Yaylacilik Activities in the Eastern Blacksea Region: Giresun Kümbet Yaylasi. Gazi University. Education Faculty Review. Volume 23 Issue 3 Ankara. 2003. 55-69) 
[13]. Doğanay H., Zaman S., Oba-Yayla Yerleşmelerine Tipik İki Örnek: Çambaşı ve Turnalık Obaları (Ordu İli). Türk Coğrafya Dergisi. Sayı: 43. İstanbul. 2004. 1-30 (Typical Two Examples of Oba-Yayla Settlements: Çambasi and Turnalik Yaylas (Ordu Province). Turkish Geographical Review. Issue: 43. Istanbul. 2004. 1-30)

[14]. Doğanay S., Doğu Karadeniz'de Yayla Merkezlerine Yeni Bir Örnek: Taşköprü Yaylası. Doğu Coğrafya Dergisi. Cilt 16. Say1: 26 Erzurum. 2011. 223-240 (A New Example of Yayla Center in Eastern Black Sea Region: Taşköprü Yaylasi. Eastern Geographical Journal. Volume 16 Issue 26 Erzurum. 2011. 223-240)

[15]. Tunçel H., et al, Doğu Karadeniz Dağları'nda Yaylacıllk. Frrat Üniversitesi Sosyal Bilimler Dergisi. Cilt:14 Sayı 2 Elazığ. 2004. 49-66 (Transhumans in the Eastern Blacksea Mountains. Firat University Journal of Social Sciences. Volume: 14 Issue 2 Elazig. 2004. 4966)

[16]. Yürüdür E., Yakın Mesafeli Yaylacıllk Faaliyetlerine Bir Örnek: Yaylacık Dağı'nda (Tokat) Yaylacılık. Doğu Coğrafya Dergisi. Cilt 11. Say1 16 Erzurum. 2006. 247272 (An Example of Close-Distance Transhumans Activities: Yaylacik Mountain (Tokat). Eastern Geographical Journal. Volume 11 Issue 16 Erzurum. 2006. 247-272)

[17]. Zaman M., Tonya İlçesinde Oba-Yayla Yerleşmeleri ve Yaylacıllk. Doğu Coğrafya Dergisi. Cilt 6. Sayı 3 Erzurum. 2000. 221-244 (Oba-Yayla Settlements and Transhumans in Tonya District. Eastern Geographical Journal. Volume 6 Number 3 Erzurum. 2000. 221-244)

[18]. Zaman M., Doğu Karadeniz Kıyı Dağlarında Yaylalar ve Yaylacllı. Atatürk Üniversitesi Yayını. Erzurum. 2007. (Yayla Settlements and Transhumans in Eastern
Blacksea Coasts Mountains. Atatürk University Publications. Erzurum. 2007)

[19]. Somuncu M., et al, Doğu Karadeniz Bölgesi Yaylalarında Çevresel Değişim. Ankara Üniversitesi Yayını. Ankara. 2012. (Environmental Change in the Eastern Blacksea Region Yaylas. Ankara University Publication. Ankara. 2012)

[20]. Özdemir Ü., Çelikoğlu Ş., Batı Karadeniz'de Rekreasyonel Açıdan Giderek Önemi Artan Bir Yaylacılık Sahası: Uluyayla. Doğu Coğrafya Dergisi. Cilt 19. Say1 32. Erzurum. 2014. 79-100 (An Increasing Importannce of Trnashumans Area from a Recreational Point of View in the Western Blacksea: Uluyayla. Eastern Geographical Journal. Volume 19, Number 32. Erzurum. 2014. 79-100)

[21]. Taştemir M., XVI. Yüzyılda Adıyaman (Behisni, Hısn-ı Mansur, Gerger, Kâhta) Sosyal ve İktisadi Tarihi. Türk Tarih Kurumu Yayını. Ankara. 1999. (Social and Economic History of Adlyaman (Behisni, Hisn-l Mansur, Gerger, Kâhta) in the XVIth Century. Turkish Historical Society Publication. Ankara. 1999)

[22]. Öztürk S., Osmanlı Döneminde Adlyaman'ın Sosyal ve Ekonomik Özellikleri. Medeniyetler Kavşağı Adıyaman Sempozyumu Kitabı. Adıyamanlılar Vakfi Yayını. İstanbul. 2008. (Social and Economic Characteristics of Adlyaman in the Ottoman Period. Civilizations Junction Adıyaman Symposium Book. Publications of the Adiyamanlilar Foundation. Istanbul. 2008) 


\title{
Sự chuyển biến về mặt không gian và kinh tế - xã hội trong đời sống du mục ở Quận Gerger (Đông Nam Thổ Nhĩ Kỳ)
}

\author{
Muzaffer BAKIRCI \\ Đại học Istanbul \\ Email liên hệ tác giả: mubak@istanbul.edu.tr
}

Ngày nhận bản thảo: 10-10-2017; Ngày chấp nhận cho đăng bài: 12-12-2017; Ngày đăng bài: 30-6-2018

Tóm tắt-Thổ Nhĩ Kỳ ngay từ những năm 80 của thế kỷ trước đã bước vào một cuộc biến chuyển nhanh chóng. Những cuộc di dân từ nông thôn ra thành thị một cách không kiểm soát xuất hiện tù khoảng thời gian ấy, không chỉ khiến vùng nông thôn trở nên "rỗng không" mà còn là nguyên nhân của nhiều vấn đề, cấu trúc khác đối với nhiều đô thị.

Một trong những sinh kế chịu ảnh hưởng nhiều nhất từ những biến chuyển nông thôn ở Thổ Nhĩ Kỳ chính là đời sống du mục. Chăn nuôi động vật bán du cư là một nghề phổ biến trên hầu hết các vùng của Thổ Nhĩ Kỳ và lối sống này đang đối mặt với nhiều thay đổi quan trọng.

Quận Gerger ở miền đông nam Thổ Nhĩ Kỳ là một trong những nơi từng trải qua những thay đổi đáng chú ý như thế. Đời sống du mục có mặt từ hàng thế kỷ, ngày nay đang đối mặt với những chuyển biến quan trọng về mặt không gian, kinh tế và văn hóa xã hội. Về vấn đề chuyển biến không gian, sự thoái trào của hoạt động chăn nuôi gia súc dựa điều kiện môi trường và việc sản xuất nông nghiệp không thường xuyên đang trở nên ngày càng phổ biến. Trong khi đó, sự phân biệt các loại hình cư dân lại ngày càng trở thành một vấn đề quan trọng. Chăn nuôi gia súc - hoạt động kinh tế chính yếu trong quá khứ, nay biến mất theo một tần suất cao và không còn là một hoạt động mang lại thu nhập điều cho thấy sự chuyển biến về mặt kinh tế đang diễn ra. Ngoài ra, sự chuyển biến về mặt văn hóa xãa hội xuất hiện bởi nhiều hệ thống quy tắc xã hội đã từng được thi hành rất sát sao trong quá khứ nay dần biến mất.

Tù̀ khóa-Thổ Nhĩ Kỳ; Quận Gerger; Du mục; Không gian; Kinh tế-xã hội; Chuyển biến 